\title{
Molecular detection of Porcine Reproductive and Respiratory Syndrome Virus, Porcine Circovirus 2 and Hepatitis E Virus in oral fluid compared to detection in faeces and serum.
}

Jan Plut ( Jan.Plut@vf.uni-lj.si )

Univerza v Ljubljani https://orcid.org/0000-0003-3456-7438

Urska Jamnikar-Ciglenecki

Univerza v Ljubljani Veterinarska fakulteta

Marina Stukelj

Univerza v Ljubljani Veterinarska fakulteta

Research article

Keywords: Pig oral fluid, Faeces, Serum, PRRS, Hepatitis E virus, PCV2

Posted Date: November 25th, 2019

DOl: https://doi.org/10.21203/rs.2.17672/v1

License: (c) (1) This work is licensed under a Creative Commons Attribution 4.0 International License. Read Full License

Version of Record: A version of this preprint was published at BMC Veterinary Research on May 27th, 2020. See the published version at https://doi.org/10.1186/s12917-020-02378-4. 


\section{Abstract}

Background Porcine Reproductive and Respiratory Syndrome Virus (PRRSV), Porcine Circovirus Type 2 (PCV2) and Hepatitis E virus (HEV) are common and economically important viral disease causative agents detected in pig oral fluid (OF), faeces and serum at some infection stages. The purpose of this study was to detect and compare PRRSV, PCV2 and HEV on six pig farms to determine which of the three sample types, OF, faeces or serum is appropriate for the diagnosis of these viruses in different pig categories. The following pig categories were included in the study: 5 weeks-old (w/o), $7 \mathrm{w} / \mathrm{o}, 9 \mathrm{w} / \mathrm{o}, 11$ $\mathrm{w} / \mathrm{o}$ weaners, fatteners and breeding sows. Pursuant to preliminary detection of each pathogen at the selected farms, OF samples, faeces, serum pools and 10 individual sera were tested with PCR for each age category. If any of the viruses were found in pools of faeces and OF, then faeces and OF from positive farms were tested separately for each pig category. The nucleic acid isolated from the samples was detected with RT-PCR, PCR and real-time RT-PCR for PRRSV, PCV2 and HEV respectively.

Results PRRSV and HEV were detected on one farm and PCV2 on three others, positive results being more often obtained from the OF than from the faeces of the same animals. Testing of 10 individual sera samples from pigs from the same group of pigs was also performed, and detected the virus in individual sera and OF in the same pig category, with some exceptions: PRRSV was detected in the OF of fatteners but was absent in their sera; PCV2 was detected in sera but absent in group samples or vice-versa but OF sample, whereas HEV was detected in the OF of the youngest, $5 \mathrm{w} / \mathrm{o}$ weaners and absent in sera of the same age group.

Conclusions The primary finding of the study is that OF is a welfare-friendly, non-invasive and highly efficient matrix for pathogen detection, thus evidencing the utility of pig OF as a matrix in which each of the three viruses considered can be detected with the highest probability.

\section{Background}

Oral fluid (OF), consisting of oral salivary gland products and mucous transudate, has been used for the detection of different pathogens and antibodies in humans and animals; its use for the detection of antiMalta fever antibodies in humans was first described in 1909 [1]; in terms of swine disease Porcine Reproductive and Respiratory Virus (PRRSV), such antibodies were initially isolated from individual animal buccal samples in 1997 [2]. Increased utilisation of pig OF for the molecular diagnosis of the pathogens was presented in 2008 by Prickett et al. [3]. Pursuant to these studies, pig OF sampling for the detection of pig disease was further acknowledged by means of the first comprehensive studies of methodology, including sampling procedure, containment and transport, pre-diagnostic processing of OF samples, and comparison with other samples previously used for the detection of PRRSV and PCV2. One of the main reasons for choosing OF sampling over other sampling methods is its stress-free ease of use vis à vis disease monitoring and consequent positive impact on pig welfare [4]. The use of OF analysis in pig health care has steadily progressed since its start and is increasing in importance; in the US, numbers have risen from 21,000 tested samples in 2010 to 370,000 samples in 2016 [5]. However, Slovenian pig 
farming and pig health care does not make full use of this diagnostic method. The Slovenian pig industry has markedly declined since our entry to the European Union in 2004; our production has fallen to a mere 259,000 pigs in 2018 , having only two farms with 3,000 breeding animals making us one of the smallest pig production industries in Europe, importing almost $80 \%$ of our pork product wants. Ninety-five percent of Slovenian farms are "backyard" farms with less than 10 breeding animals and $47.7 \%$ of all farms own just one or two animals. Our health care declarations do not provide mandatory protective vaccinations, individually necessary biosecurity measures or tracking of some economically important infective diseases (data from www.pig333.com, Slovenia Statistical Office).

From first detection of a limited number of pathogens in OF, mostly PRRSV [3], researchers now endeavour to expand the spectrum of important pathogens, specific antibodies against them, for example Classical Swine Fever [6] and bacteria Lawsonia Intracellularis [7], and other activities covering a field like proteomic [8]. Twelve scientific articles have been published in different scientific journals since 2018, excluding conference contributions, abstracts and others according to the NCBI database (https://www.ncbi.nlm.nih.gov/pubmed), about PRRSV and PCV2 in oral fluid, mostly related to sampling strategy, comparison of pooled versus individual samples, and detection of viral nucleic acid and antibodies against them. But when it comes to HEV, only one scientific article has been published about the detection of HEV RNA in pig OF since 2014 and, despite the promising results obtained in that study, faeces remain the primary sample of interest regarding live pigs [9].

PRRSV, PCV2 and HEV are all important viral disease causative agents: PRRSV and PCV2 are exclusively pig and very common diseases resulting in huge economic loss [10-12]; HEV is potentially lethal for humans in terms of chronic hepatitis for certain populations and contaminated pork and meat products are potential sources of human infection, especially HEV genotype 3 , which is predominantly present in Europe $[13,14]$. Individual serum samples are still most frequently used for the definite detection of most pig diseases in herds. Because blood drawing is technically demanding, bloody and potentially stressful, and sometimes fatal for pigs, other samples are becoming increasingly popular; OF is amongst these samples [15]. The most likely natural route of infection for all three viruses in field conditions is the nasaloral route, meaning that agents are present in OF at disease stages; however, the pathogenesis of each disease differs significantly and detection of the virus' genetic material for molecular diagnostics is only present for isolation in different samples for a limited amount of time, making appropriate sampling method utilisation challenging. PRRSV and PCV2, for example, have long-lasting recurring viremic periods: when PRRS viremia starts in the suckling period it can last more than 60 days, throughout the whole weaning period; it lasts 35-42 days in fatteners, up to one week in breeding pigs for PRRS, and up to 70 days for PCV2 in post-weaning and later during fattening $[16,17]$. In terms of HEV, viremia can be short-lasting, even absent [18], necessitating other sampling for in vivo detection, OF being amongst them. One characteristic for all these diseases is that they can be detected in different organ systems after circulation virus elimination, which can be used to our advantage when using samples other than sera for analysis $[9,17,19]$. Using some of this information, the purpose of this study was to detect and compare PRRSV, PCV2 and HEV in the field at different pig enterprises to determine which of these 
samples, OF, faeces or serum, is the most appropriate for the diagnosis of these viruses in different pig categories.

\section{Results}

The pooled samples of OF and faeces from all categories from each farm were tested $(10 \mu \mathrm{L}$ of each eluent) for the preliminary detection of each of the three pathogens to determine if farms were either positive or negative in terms of PCR Reaction (Table 1).

The pooled group samples from farms 1 and 3 were negative for all three pathogens, whilst all of the samples from the other farms evidenced positive results for at least one pathogen in OF and/or faeces (Table 1).

Table 1: Preliminary testing of pooled samples of OF and faeces for each farm

\begin{tabular}{|c|c|c|c|c|c|c|c|c|}
\hline \multirow[t]{2}{*}{ selected pathogens } & & & \multicolumn{6}{|c|}{ Farm } \\
\hline & & & 1 & 2 & 3 & 4 & 5 & 6 \\
\hline & \multirow[t]{2}{*}{ PRRSV* } & OF & neg. & neg. & neg. & neg. & pos. & neg. \\
\hline & & faeces & neg. & neg. & neg. & neg. & neg. & neg. \\
\hline & \multirow[t]{2}{*}{ PCV2** } & OF & neg. & pos. & neg. & pos. & neg. & pos. \\
\hline & & faeces & neg. & pos. & neg. & neg. & neg. & pos. \\
\hline & \multirow[t]{2}{*}{$\mathrm{HEV} \star \star \star$} & $\mathrm{OF}$ & neg. & neg. & neg. & neg. & neg. & pos. \\
\hline & & faeces & neg. & neg. & neg. & neg. & neg. & pos. \\
\hline
\end{tabular}

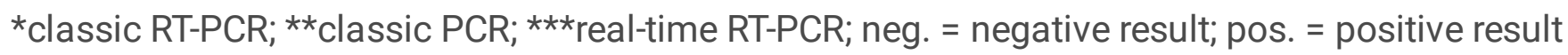

After isolated nucleic acid from group samples of OF and faeces from all categories were pooled, a preliminary classification of the farm was made to determine the presence of each of the three viruses

After pooled samples were determined positive, samples from each category were individually tested to determine in which category of pigs the pathogen is found, as well as if the pathogen can be discovered in all three different samples with PCR (Table 2). If any of the viruses were detected in OF or faeces, all 10 sera samples from the same pig group were individually tested for the same virus; if both OF and faeces tested negative, two pools of five sera were tested for all three pathogens to confirm the initial result; if serum pools were also negative, individual sera samples were not tested (NT).

PRRSV was discovered on Farm 5; OF samples were deemed positive by means of RT-PCR for 7, 9 and 11 $\mathrm{w} / \mathrm{o}$ weaners and fatteners (estimated $15 \mathrm{w} / \mathrm{o}$ ), whilst all faecal samples, except the one from $9 \mathrm{w} / \mathrm{o}$ weaners, were negative. PRRSV RNA was detected in all weaner sera samples, whilst all samples from fatteners were negative. 
Farms 2, 4 and 6 were PCV2 positive; DNA could only be detected in weaners, but fatteners and breeding sows were all negative. On Farms 2 and 6, DNA was detected in OF and faeces samples from the same category, but on Farm 4, only OF from 11 w/o weaners were positive and faeces negative by means of classic PCR. PCV2 DNA was only discovered in weaner sera on Farm 6; and weaner sera from the other two farms was PCV2 clear.

HEV was detected in the youngest weaners, aged 5, 7 and 9 weeks old, on Farm 6; both OF and faeces samples testing positive, whilst only one serum sample from $7 \mathrm{w} / 0$ weaners and two sera samples from 9 w/o weaners were deemed HEV RNA positive using quantitative RT-PCR.

Samples were compared using Fisher's exact test, and this evidenced strong correlation between faecal and OF samples when determining PCV2 $(p=0.001)$, whereas for other samples, correlation could not be characterized as statistically significant.

Table 2: Presence of viruses in OF, faeces and serum on each farm in different pig categories 


\begin{tabular}{|c|c|c|c|c|c|c|c|c|}
\hline & & Farm & $\begin{array}{l}5 \\
w / 0\end{array}$ & 7 w/o & 9 w/o & $\begin{array}{l}11 \\
w / 0\end{array}$ & Fatteners & $\begin{array}{l}\text { Breeding } \\
\text { sows }\end{array}$ \\
\hline \multirow[t]{4}{*}{ PRRSV* } & OF & \multirow[t]{4}{*}{5} & neg. & pos. & pos. & pos. & pos. & neg. \\
\hline & faeces & & neg. & neg. & neg. & pos. & neg. & neg. \\
\hline & serum pool & & neg. & $N T$ & $N T$ & $N T$ & $N T$ & neg. \\
\hline & $\begin{array}{l}\text { individual } \\
\text { sera }^{1}\end{array}$ & & $N T$ & $10 / 10$ & $10 / 10$ & $10 / 10$ & $0 / 10$ & $N T$ \\
\hline \multirow[t]{12}{*}{$P C V 2^{* *}$} & OF & \multirow[t]{4}{*}{2} & neg. & neg. & pos. & neg. & neg. & neg. \\
\hline & faeces & & neg. & neg. & pos. & neg. & neg. & neg. \\
\hline & serum pool & & neg. & neg. & neg. & pos. & pos. & neg. \\
\hline & $\begin{array}{l}\text { individual } \\
\text { sera }^{1}\end{array}$ & & $N T$ & $N T$ & $0 / 10$ & $8 / 10$ & $3 / 10$ & $N T$ \\
\hline & OF & \multirow[t]{4}{*}{4} & neg. & neg. & neg. & pos. & neg. & neg. \\
\hline & faeces & & neg. & neg. & neg. & neg. & neg. & neg. \\
\hline & serum pool & & neg. & neg. & pos. & neg. & neg. & neg. \\
\hline & $\begin{array}{l}\text { individual } \\
\text { sera }^{1}\end{array}$ & & $N T$ & $N T$ & $6 / 10$ & $0 / 10$ & $N T$ & $N T$ \\
\hline & OF & \multirow[t]{4}{*}{6} & pos. & pos. & pos. & neg. & neg. & neg. \\
\hline & faeces & & pos. & pos. & pos. & neg. & neg. & neg. \\
\hline & serum pool & & $N T$ & $N T$ & $N T$ & neg. & neg. & neg. \\
\hline & $\begin{array}{l}\text { individual } \\
\text { sera }^{1}\end{array}$ & & $2 / 10$ & $3 / 10$ & $9 / 10$ & $N T$ & $N T$ & $N T$ \\
\hline \multirow[t]{4}{*}{$H E V^{\star \star *}$} & OF & \multirow[t]{4}{*}{6} & pos. & pos. & pos. & neg. & neg. & neg. \\
\hline & faeces & & pos. & pos. & pos. & neg. & neg. & neg. \\
\hline & serum pool & & $N T$ & $N T$ & $N T$ & neg. & neg. & neg. \\
\hline & $\begin{array}{l}\text { individual } \\
\text { sera }^{1}\end{array}$ & & $0 / 10$ & $1 / 10$ & $2 / 10$ & $N T$ & $N T$ & $N T$ \\
\hline \multicolumn{9}{|c|}{ neg. = negative result } \\
\hline \multicolumn{9}{|c|}{ pos. $=$ positive result } \\
\hline
\end{tabular}


* classic RT-PCR

** classic PCR

${ }^{\star \star \star}$ real-time RT-PCR

${ }^{1}$ ten individual sera were tested from each pig age group. Results are shown pos./all tested sera.

\section{Discussion}

Pig OF has been regarded as one of the most appropriate samples for pathogen detection for some years now $[3,20,21]$. Major research in this field started toward the end of the previous decade with the goal of finding a way to make sample collection less stressful for pigs, and easier, faster and cheaper for those performing sampling $[4,22]$. Previous studies provide some insight into OF collection, pre-diagnostic procedures and results regarding different pathogens; results are mostly promising; nevertheless, unanswered questions regarding methodology remain, including incomplete standardised procedures in terms of pre-diagnosis and its variable results when compared to other individual or group samples, e.g. serum, nose swabs, post-mortem isolation from organs, and group faeces samples [23, 24].

Our study compared group OF samples with group faecal samples and individual sera samples from different pig categories from six Slovenian farms, each with varying amounts of disease history data. PRRSV, PCV2 and HEV were chosen because these viruses represent quite common pathogens in terms of the pig industry and are either economically important for pig health, or represent a possible food safety threat, such as HEV. All diseases have their own pathophysiological characteristics and, therefore, detectable in a variety of infection stage samples. Even though OF samples were not taken from individual pigs, results show they are of great use for determining viral presence on farms in relation to our considered diseases and group sampling is seen to be more effective than group faecal samples collected from pig farms, probably due to the presence of higher amounts of inhibitory substances in faeces [23-25]. Statistically significant correlation between OF and faeces samples was shown with more than $95 \%$ probability ( $p=0.001$ ); in other cases, correlation was disputed by a Fisher's test value of $p$ $<0.05$, although results favoured OF over other samples in terms of PRRS and HEV detection. In comparison to individual sera samples, OF showed complementary results, variation noticed in PCV2 DNA detection. OF samples were collected from a relatively small number of pigs compared to the study by Nielsen et. al in 2018 [20] (a maximum up to 20 pigs in a group pen); samples were collected pursuant to all pigs being observed chewing the ropes and faeces were added directly from the rectum of the animals in the pen to assure samples were representative. Even though sensitivity falls by an estimated 27-100\% when five sera samples were pooled when compared to individual samples, our results are of great utility, especially in terms of prevalence studies [26]. 
When talking about PRRSV, PCV2 and HEV, several studies have investigated simultaneous co-infection with two viruses. This happened on Farm Six, where PCV2 and HEV was found in weaning pigs of all age. Salines et al. described the same virus combination in 2019, finding a statistically significant concentration of $\mathrm{HEV}$ in faeces during infection, and that seroconversion for anti-HEV antibodies takes longer and the transmission rate for HEV was approximately three times higher in co-infected pigs [27]. As HEV is an observed differential in this case, the findings could be a result of immune system modification caused by the immunosuppressive effect of PCV2. Another study by the same author states that immunosuppressive virus presence increases the viral concentration of HEV in the liver at slaughter [28]. The situation was harder to assess because our primary focus was co-infection and our environment was uncontrolled. But looking from a viewpoint opposite to Salines, PCV2 was detected in weaner sera and, generally, in more categories than on the other two farms. The farm owner stated that he did experience trouble with a higher mortality rate and poor average daily gain and wasting during this stage. Yang et al. evidenced fatalities in weaned pigs co-infected with PCV2 and HEV [29] in 2015. HEV, is usually depicted as benign and not as a swine pathogen, but it may be part of a multifactor clinical outbreak catalyst and negatively affect pork quality.

PRRSV was only found on Farm 5, a farm that had previously experienced disease outbreak. Even though Farm 5 acclimates its gilts before transferring them to the breeding herd, transmission to offspring still occurs: youngest weaners are disease-free pursuant to colostral immunity, the eldest get infected. Viral RNA was present in OF and sera tested positive for weaners aged 7, 9 and 11 weeks; PRRSV RNA was only found in the faeces of $11 \mathrm{w} / \mathrm{o}$ weaners, as evidenced in a previous study, whereby PRRSV only appears in faeces intermittently [30]. Fatteners seem to eliminate the virus from sera, presumably after the appearance of antibodies in sera; even so, the virus seems to persist in OF for longer periods of time [19], meaning OF can be a sample of choice for diagnostic use, especially for longer periods after infection, that is, during the weaning-fattening period and for replacement gilts before entering the breeding herd, when the virus is eliminated from the bloodstream, but present in other tissue.

Although PCV2 is considered ubiquitous, its presence was only detected on half of the farms concerned, of which only one used anti-PCV2 vaccination as part of their preventive program. On Farm 2, where pregnant sows were vaccinated against PCV2 with a commercially-sourced vaccine, the virus was found in the OF and faeces of $9 \mathrm{w} / \mathrm{o}$ weaners, but none of the younger weaners were viremic. However, the situation was different in relation to 9 and $11 \mathrm{w} / \mathrm{o}$ weaners, where PCV2 was not found in OF and faeces but was present in $80 \%$ and $30 \%$ of pig sera respectively. It seems that the immunity acquired by means of preventive programs wanes between 9 and $11 \mathrm{w} / \mathrm{o}$ and, as the virus is still present in the environment, weaners and fatteners become viremic. In the case of Farm 2, it looks as if their prevention programme does not protect pigs from the viremic phase entirely, even though $3 \mathrm{w} / \mathrm{o}$ suckling piglets are vaccinated; viral DNA could be later detected in the OF and faeces of $9 \mathrm{w} / \mathrm{o}, 11 \mathrm{w} / \mathrm{o}$ weaners and fattening pigs, as well as in the sera of the last two categories. A 2016 study by Feng et al. suggests that vaccination should also be facilitated for $3 \mathrm{w} / \mathrm{o}$ piglets, as it extends protection against the pathogen until pigs are up to 25-weeks old, regardless of maternally-derived antibody presence [31], as vaccination against PCV2 is now used as a preventive measure on Slovenian farms. PCV2 was detected on Farm 4; a local 
veterinarian stated that PCV2 had never been detected in any samples taken from it and that it did not vaccinate. The virus was only detected in the sera of $60 \%$ of 9 w/o weaners on Farm 4, but not in OF; the situation reversed for $11 \mathrm{w} / \mathrm{o}$ weaners, which could mean that pigs get infected by the virus somewhere around $9 \mathrm{w} / \mathrm{o}$ and eliminate it from their bloodstreams in a short period of time, also confirmed in a study by Grau-Roma et al. Pigs are protected by maternal immunity until week 8 then by blood viral load peaks when $10 \mathrm{w} / \mathrm{o}$; thereon, the virus is eliminated from the bloodstream and then from the organism [32]. Nonetheless, OF seems to be a good diagnostic tool for farm prevalence determination; research by Nielsen et al. stated that it is even more efficient than sera utilisation [20] in 2018. On Farm 6, PCV2 was detected in the youngest categories of weaners (5, 7 and $9 \mathrm{w} / \mathrm{o})$ : pigs on this farm had not been vaccinated. PCV2 was detected in both faeces and OF, and sera; our statistical analysis indicates that OF is more effective for detecting viruses than faeces ( $p=0.001)$; infection timeline and viremia onset are in accordance with previous studies: most pigs were infected at 4-11 w/o and repetitive viremia is present from day 7 to day $70[32,33]$.

Farm 6, also PCV2-positive, was the only HEV-positive farm, despite the virus being described as ubiquitous [34]. The three youngest categories of weaners were determined HEV-positive in terms of OF and faeces by means of RT-PCR. The results show that disease vines out in older categories, in accordance with previous reports: pigs get infected at around 2-3 months of age and this persists in some excrement for 3-7 weeks. If viremia appears, it is usually present for short periods of time, between one and two weeks $[18,34]$; none of the weaners were viremic by week 5 ; one in ten were viremic at 7 weeks, and two in ten were viremic at week 9 , which indicates that HEV only sporadically spreads into the bloodstream. Although the virus is supposed to replicate in the lower gastrointestinal tract [35], OF concentration is seemingly high enough for molecular detection. Compared to group faeces samples, OF is collected more easily and all pigs from the group chew on the ropes. Faeces for collection are not evenly distributed over pens' floors: some excrement will be old, some will fall through floors' slats. If faeces are obtained directly from the rectum of animals, the procedure can be time-consuming and stressful for pigs. As aforementioned, statistical analysis supports the usefulness of pig OF for detecting PCV2 DNA, but did not prove or disprove correlation in cases of HEV RNA detection in OF, faeces or serum due to the low number of positive samples in our study.

\section{Conclusion}

This study evidences that OF is an efficient matrix for the detection of PRRSV, PCV2 and HEV nucleic acid. Sera samples are usually tested for PRRSV and PCV2 presence, faeces for HEV presence in live pigs. Our study shows that the same pathogens can be detected by means of OF with equal or even greater certainty. Oral fluid is as good as, or even better for PRRSV and HEV detection than individual sera samples and faeces. OF was statistically more efficient than faeces $(p=0.001)$ for detecting PCV2, but results were not completely complementary vis à vis serum detection.

\section{Methods}




\section{Animals and Farms}

Samples were taken at six different pig farms: one small two-site farm (Farm number 1) with approximately 500 breeding sows, three small one-site farms with less than 100 breeding sows (Farms number 2, 3 and 6), and two large one-site farms (Farms 4 and 5) with more than 1,000 breeding sows. The smallest three farms in our study do not quarantine before gilt replacement, but farms 2 and 6 confirm newly bought animals are PRRS antibody negative. Epidemiologic data for Farm 3 was unknown, and preventive vaccination against PCV2 or PRRS is not implied. Animals were placed in separate crates and divided into age-dependent categories at all farms: 5 weeks-old (w/o); $7 \mathrm{w} / 0 ; 9 \mathrm{w} / 0 ; 11 \mathrm{w} / \mathrm{o}$ weaners; fatteners; and breeding sows. Vaccination against PCV2 is part of Farm 2's preventive protocol. Other farms do not apply any on-site preventive measures against our selected pathogens. No ethics approval by the Slovenian Ministry of Agriculture, Forestry and Food's Administration of the Republic of Slovenia for Food Safety, Veterinary Sector and Plant Protection was needed for the purposes of this study.

\section{Samples}

Ten individual blood samples were drawn from each group from the anterior vena cava and a group of OF samples was obtained by means of the cotton ropes provided in the IDEXX Oral Fluid Collection Kit from the same groups blood was drawn from. Undyed-Cotton 3-Strand Twisted Rope was hung above an open spot in the middle of pens away from feed and drinking water for half-an-hour; after which, the rope was removed and OF squeezed from it into sterile $50 \mathrm{ml}$ screw cap plastic containers. A group sample of fresh faeces was also collected from these pigs from random pen sites and a smaller amount directly from recta into $100 \mathrm{ml}$ sterile screw cap plastic containers. Samples were transported to the laboratory in a refrigerated box at $4{ }^{\circ} \mathrm{C}$. OF samples were centrifuged for $10 \mathrm{~min}$ at $2000 \times \mathrm{g}$ and supernatant was stored at $-70{ }^{\circ} \mathrm{C}$. A $10 \%$ suspension in RPMI-1640 (Thermo Fisher Scientific, Carlsbad, CA, USA) was prepared from each faecal sample. Suspensions were centrifuged at 2000 $\mathrm{g}$ for 10 minutes before the supernatant was transferred to sterile $20 \mathrm{ml}$ screw cap plastic containers and stored at $-70{ }^{\circ} \mathrm{C}$ before further testing. Sera were centrifuged for $10 \mathrm{~min}$ at $3000 \times \mathrm{g}$ after coagula formation. These samples were stored individually in $20 \mathrm{ml}$ sterile cryotubes at $-70^{\circ} \mathrm{C} .10 \mu \mathrm{L}$ of OF eluent and faeces samples from each of the six pig categories were taken and pooled to preliminarily determine whether animals on the farms were virus-positive. If any of the viruses were found in these pools, then faeces and OF from positive farms were tested separately for each pig category. Ten individual sera samples were obtained from pigs from each category on every farm. If any of the viruses were detected in OF or faeces, all 10 sera samples from the same pig group were individually tested for the same virus; if both OF and faeces tested negative, two pools of 5 sera $(140 \mu \mathrm{L})$ were tested for all three pathogens to confirm the initial result; if serum pools were also negative, individual sera samples were not tested.

\section{DNA/RNA extraction}


DNA and RNA samples were extracted manually using the QIAamp Viral RNA Mini Kit (Qiagen, Germany), according to manufacturer instructions. Nucleic acid was extracted from $140 \mu \mathrm{L}$ of the supernatant accordingly and eluted in $60 \mu \mathrm{L}$ of elution buffer.

\section{RT-PCR for PRRS detection}

RT-PCR by means of the One-Step RT-PCR Kit (Qiagen, Germany) and specific primers (Table 3) was performed to specifically detect PRRSV. The final reaction volume of $25 \mu \mathrm{L}$ was composed of $5 \mu \mathrm{L} 5 \mathrm{x}$ PCR buffer, $11 \mu \mathrm{L}$ DNase/RNase-free water, $1 \mu \mathrm{L}$ of $10 \mathrm{mM}$ dNTP mix, $0.5 \mu \mathrm{L}$ of each primer $(20 \mathrm{pmol} / \mu \mathrm{L})(\mathrm{Table}$ 3), $1 \mu \mathrm{L}$ RT-PCR Enzyme Mix, and $6 \mu \mathrm{L}$ of RNA. Amplification was performed by means of the Mastercycler Nexus Gradient (Eppendorf, Germany) with thermocycling conditions of $30 \mathrm{~min}$ at $50^{\circ} \mathrm{C}$ and $15 \mathrm{~min}$ at 94 ${ }^{\circ} \mathrm{C}$, followed by 40 cycles of denaturation at $94{ }^{\circ} \mathrm{C}$ for $30 \mathrm{sec}$, annealing at $60^{\circ} \mathrm{C}$ for $30 \mathrm{sec}$, elongation at $72{ }^{\circ} \mathrm{C}$ for $14 \mathrm{~min}$, followed by final elongation at $72{ }^{\circ} \mathrm{C}$ for $10 \mathrm{~min}$. PCR products were visualised on $1.8 \%$ $(\mathrm{w} / \mathrm{v})$ agarose gel according to the expected size of the PCR product (Table 3$)$.

\section{PCR for PCV2 detection}

Platinum PCR SuperMix (Invitrogen) was used for PCV2 detection, a $25 \mu \mathrm{L}$ reaction composed of $21.5 \mu \mathrm{L}$ Platinum PCS SuperMix, $0.75 \mu \mathrm{L}$ of each specific primer (Table 3), and $2 \mu \mathrm{L}$ of DNA used for this purpose; Mastercycler Nexus Gradient (Eppendorf, Germany) thermal conditions were 2 min at $94{ }^{\circ} \mathrm{C}$, followed by 35 cycles of denaturation at $94^{\circ} \mathrm{C}$ for $30 \mathrm{sec}$, annealing at $55^{\circ} \mathrm{C}$ for $30 \mathrm{sec}$, elongation at $72{ }^{\circ} \mathrm{C}$ for $1 \mathrm{~min}$, followed by final elongation at $72{ }^{\circ} \mathrm{C}$ for $7 \mathrm{~min}$. PCR products were visualised on $1.8 \%(\mathrm{w} / \mathrm{v})$ agarose gel according to the expected size of the PCR product (Table 3 ).

\section{Real-Time RT-PCR for HEV detection}

Real-time RT-PCR was performed by means of SuperScript III Platinum One-Step Quantitative RT-PCR System (Thermofisher Scientific) for HEV detection, a $25 \mu \mathrm{L}$ final reaction composed of $12.5 \mu \mathrm{L} 2 \mathrm{x}$ reaction mix, $0.5 \mu \mathrm{L} 50 \mathrm{mM} \mathrm{MgSO}_{4}, 0.5 \mu \mathrm{L}$ ROX Reference Dye (1:10), $5 \mu \mathrm{L}$ DNase/RNase-free water, $0.75 \mu \mathrm{L}$ of each

primer $(20 \mathrm{pmol} / \mu \mathrm{L}), 0.5 \mu \mathrm{L}$ of specific probe $(5 \mathrm{pmol} / \mu \mathrm{L})($ Table 3$), 0.5 \mu \mathrm{L}$ SuperScript ${ }^{\circledR}$ III/Platinum ${ }^{\circledR}$ Taq Mix, and $4 \mu \mathrm{L}$ of RNA used for this purpose. The reaction was performed by means of QuantStudio3 (Thermo Fisher Scientific, Massachusetts, USA) under thermocycling conditions of $15 \mathrm{~min}$ at $50^{\circ} \mathrm{C}$ and 10 min at $95^{\circ} \mathrm{C}$, followed by 45 cycles of denaturation at $95^{\circ} \mathrm{C}$ for $15 \mathrm{sec}$, and annealing at $55^{\circ} \mathrm{C}$ for 1 $\min$.

Table 3: Specific primers and probes used in this study. 


\begin{tabular}{|c|c|c|c|c|}
\hline $\begin{array}{l}\text { Detected } \\
\text { virus }\end{array}$ & Name & Primer and probe sequence $\left(5^{\prime}-3^{\prime}\right)$ & $\begin{array}{l}\text { PCR } \\
\text { product }\end{array}$ & Reference \\
\hline \multirow[t]{2}{*}{ PRRSV } & F-P1 & CCA GCC AGT CAA TCA RCT GTG & \multirow[t]{2}{*}{291 bp } & \multirow{2}{*}{$\begin{array}{l}\text { Donadeu et al., } 1999 \\
\text { [37] }\end{array}$} \\
\hline & $\mathrm{R}-\mathrm{P} 2$ & GCG AAT CAG GCG CAC WGT ATG & & \\
\hline \multirow[t]{2}{*}{ PCV2 } & $2 \mathrm{~A}$ & CAC CTT CGG ATA TAC TGT CAA & \multirow[t]{2}{*}{501 bp } & \multirow{2}{*}{$\begin{array}{l}\text { Grierson et al., } 2004 \\
\text { [38] }\end{array}$} \\
\hline & $2 \mathrm{~B}$ & $\begin{array}{l}\text { TAC ATG GTT ACA CGG ATA TTG } \\
\text { TA }\end{array}$ & & \\
\hline \multirow[t]{3}{*}{ HEV } & JVHEV- & GGT GGT TTC TGG GGT GAC & \multirow{3}{*}{ / } & \multirow[t]{3}{*}{$\begin{array}{l}\text { Jothikumar et al., } 2006 \\
\text { [39] }\end{array}$} \\
\hline & $\begin{array}{l}\text { JVHEV- } \\
\mathrm{R}\end{array}$ & AGG GGT TGG TTG GAT GAA & & \\
\hline & $\begin{array}{l}\text { JVHEV- } \\
\mathrm{P}\end{array}$ & $\begin{array}{l}\text { 6-FAM-TGA TTC TCA GCC CTT } \\
\text { CGC-BMQ }\end{array}$ & & \\
\hline
\end{tabular}

\section{Statistical analysis}

Test results are presented with basic descriptive statistics. For each disease agent, the results from the different methods were compared using Fisher's exact test; the analysis was performed using $\mathrm{R}$ Statistical Software, version 3.6.0 (Foundation for Statistical Computing, Vienna, Austria); and P values less than 0.05 considered statistically significant.

\section{Abbreviations}

HEV: Hepatitis E virus

OF: Oral fluid

PCR: Polymerase chain reaction

PCV2: Porcine circovirus 2

PRRSV: Porcine reproductive and respiratory virus

RT-PCR: Reverse transcriptase-polymerase chain reaction

HEV: Hepatitis E virus

OF: Oral fluid

PCR: Polymerase chain reaction 
PCV2: Porcine circovirus 2

PRRSV: Porcine reproductive and respiratory virus

RT-PCR: Reverse transcriptase-polymerase chain reaction

\section{Declarations}

\section{Ethics approval and consent to participate}

Blood samples were taken as part of regular diagnostics on 6 farms participating in the Slovenian Target Research Programme CRP V4-1604 (Animal welfare including health of poultry and pigs in conventional and alternative housing systems). A verbal consent for entering on private property, animal handling and sampling was given by all farm owners; the farm visits were constantly supervised. In accordance with Directive 2010/63/EU of the European Parliament and of the Council on the protection of animals used for scientific purposes and Slovenian Animal Protection Law (Uradni list RS št. 38/2013 and 21/2018), non-experimental clinical veterinary practices and practices not likely to cause pain, suffering distress or lasting harm equivalent to, or higher than that caused by the introduction of a needle, is not considered as an experiment on animals and any consent by national ethics committee is deemed unnecessary.

\section{Consent for publication}

Not applicable.

\section{Availability of data and materials}

The datasets used and/or analyzed during the current study are available from the corresponding author on reasonable request.

\section{Competing interests}

The authors declare that they have no competing interests.

\section{Funding}

The research was funded by the Slovenian Research Agency (Research Core Funding No. P4-0092). The funding group provided the financial support to cover the costs of the material used for sampling and molecular diagnostics without intellectually contributing, collecting or interpreting.

\section{Authors' contributions}


JP contributed to field sampling, performed laboratory tests, interpreted results, and prepared the manuscript. UJC contributed to planning procedures regarding laboratory testing, overseeing laboratory diagnostics and reviewing the manuscript. MS contributed to idea and experimental design, and coordinated the experiment and field sampling. All authors have contributed to the conceptualisation of the work. All authors read and approved the manuscript before submission.

\section{Acknowledgements}

We would like to thank Mr. Shawn Thomson, English native speaker, for proofreading the article.

\section{Authors' information}

${ }^{1}$ Clinic for Ruminants and Pigs, Clinic for Reproduction and Farm Animals, Veterinary Faculty University of Ljubljana, Slovenia.

${ }^{2}$ Institute of Food Safety, Feed and Environment, Veterinary Faculty University of Ljubljana, Slovenia.

\section{References}

1. Pollaci G, Ceraulo S. Das agglutinationsvermögen einiger körperflüssigkeiten beim Mediterran-fieber [The agglutinating properties of several body fluids during Malta Fever]. Centralblatt für Bakteriologie, Parasitenkunde und Infektionskrankheiten (I). Abbott Originale. 1909;52:268-75.

2. Wills RW, Zimmerman JJ, Yoon KJ, Swenson SL, Hoffman LJ, McGinley MJ, et al. Porcine reproductive and respiratory syndrome virus: excretion routes. Vet Microbiol. 1997;57:69-81.

3. Prickett JR, Kim W, Simer R, Yoon KJ, Zimmerman JJ. Oral-fluid samples for the surveillance of commercial growing pigs for porcine reproductive and respiratory syndrome virus and porcine circovirus type 2 infections. J Swine Health Prod. 2008;16(2):86-91.

4. White D, Rotolo M, Olsen C, Wang C, Prickett J, Kittawornrat A, et al. Recommendations for pen-based oral-fluid collection in growing pigs. J Swine Health Prod. 2014; 22(3):138-141.

5. Bjustrom-Kraft J, Christopher-Hennings J, Daly R, et al. The use of oral fluid diagnostics in swine medicine. J Swine Health Prod. 2018;26(5):262-

6. Panyasing Y, Thanawongnuwech R, Ji J, Giménez-Lirola L, Zimmerman JJ. Detection of classical swine fever virus (CSFV) E2 and Erns antibody (IgG, IgA) in oral fluid specimens from inoculated (ALD strain) or vaccinated (LOM strain) pigs. Vet Microbiol. 2018;224:70- doi: 10.1016/j.vetmic.2018.08.024.

7. Barrera-Zarate JA, Andrade MR, Pereira CER, Vasconcellos A, Wagatsuma MM, Sato JPH, et al. Oral fluid for detection of exposure to Lawsonia intracellularis in naturally infected pigs. Vet $\mathrm{J}$. 2019;244:34- doi: 10.1016/j.tvjl.2018.12.003. 
8. Prims S, Van Raemdonck G, Vanden Hole C, Van Cruchten S, Van Ginneken C, Van Ostade X, et al. On the characterisation of the porcine gland-specific salivary proteome. J Proteomics. 2019;196:92doi: 10.1016/j.jprot.2019.01.016.

9. Jones TH, Muehlhauser V. Effect of handling and storage conditions, and stabilising agent on the recovery of viral RNA from pig oral fluid. J Virol Methods. 2014;198:26-31. DOI: http://dx.doi.org/10.1016/j.jviromet.2013.12.11.

10. Holtkamp D, Kliebenstein J, Neumann E, Zimmerman JJ, Rotto H, Yoder T, et al. Assessment of the economic impact of porcine reproductive and respiratory syndrome virus on U.S. pork producers. J Swine Health Prod. 2013;21:72-84.

11. Alonso C, Murtaugh MP, Dee SA, Davies PR. Epidemiological study of air filtration systems for preventing PRRSV infection in large sow herds. Prev Vet Med. 2013;112(1-2):109-17.

12. Schelkopf A, Nerema J, Cowles B, Amodie D, Swalla R, Dee S. Reproductive, productivity, and mortality outcomes in late-gestation gilts and their litters following simulation of inadvertent exposure to a modified-live vaccine strain of porcine reproductive and respiratory syndrome (PRRS) virus. Vaccine. 2014;32:4639-43. DOI: http://dx.doi.org/10.1016/j.vaccine.2014.06.073.

13. Colson P, Borentain P, Queyriaux B, Kaba, M, Moal V, Gallian P, et al. Pig liver sausage as a source of Hepatitis E Virus transmission to humans. J Infect Dis. 2010; 202(6): 825-34 DOI 10.1086/655898.

14. Stanaway JD, Flaxman AD, Naghavi M, Fitzmaurice C, Vos T, Abubakar I, et al. The global burden of viral hepatitis between 1990 to 2013: findings from the Global Burden of Disease Study 2013. Lancet. 2016;388:1081-8.

15. Ramirez A, Wang C, Prickett JR, Pogranichniy R, Yoon KJ, Main R, et al. Efficient surveillance of pig populations using oral fluids. Prev Vet Med. 2012;104:292-

16. Murtaugh MP, Xiao Z, Zuckermann F. Immunological Responses of Swine to Porcine Reproductive and Respiratory Syndrome Virus Infection. Viral Immunol. 2002;15(4):533- DOI:

10.1089/088282402320914485.

17. Rodríguez-Arrioja GM, Segalés J, Calsamiglia M, Resendes AR, Balasch M, Plana-Duran J, et al. Dynamics of porcine circovirus type 2 infection in a herd of pigs with postweaning multisystemic wasting syndrome. Am J Vet Res. 2002;63(3):354-

18. Takahashi M, Nishizawa T, Miyajima H, Gotanda Y, lita T, Tsuda F, et al. Swine hepatitis E virus strains in Japan form four phylogenetic clusters comparable with those of Japanese isolates of human hepatitis E virus. J Gen Virol. 2003;84(4):851-

19. Zimmerman JJ, Benfield DA, Dee SA, Murtaugh MP, Stadjek T, Stevenson GW, et al. Porcine Reproductive and Respiratory Syndrome Virus (Porcine Arterivirus). In: Zimmerman JJ, Karriker LA, Ramirez A, Schwartz KJ, Stevenson GW, editors. Diseases of Swine, 10th ed. Ames: lowa; 2012. p. 461-486.

20. Nielsen GB, Nielsen JP, Haugegaard J, Leth SC, Larsen LE, Kristensen CS, et al. Comparison of serum pools and oral fluid samples for the detection of porcine circovirus type 2 by quantitative real-time PCR in finisher pigs. Porcine Health Manag. 2018;4:2. doi:10.1186/s40813-018-0079-4. 
21. Prickett, JR., Johnson J., Murtaugh MP, Puvanendiran S, Wang C, Zimmerman JJ, Opriessnig T. Prolonged Detection of PCV2 and Anti-PCV2 Antibody in Oral Fluids Following Experimental Inoculation. Transbound Emerg Dis.2011;58:121- doi:10.1111/j.1865-1682.2010.01189.x

22. Prickett JR, Zimmerman JJ. The development of oral fluid-based diagnostics and applications in veterinary medicine. Anim Health Res Rev. 2010;11:207-

23. Yu Z, Morrison M. Improved extraction of PCR-quality community DNA from digesta and fecal samples. BioTechniques. 2004;36(5):808-

24. Rådström, $P$, Knutsson, R, Wolffs $P$, Lövenklev $M$, and Löfström C. Pre-PCR processing. Mol Biotechnol. 2004;26:133. https://doi.org/10.1385/MB:26:2:133.

25. Malorny B, Hoorfar J. Toward Standardization of Diagnostic PCR Testing of Fecal Samples: Lessons from the Detection of Salmonellae in Pigs. J Clin Microbiol. 2005;43(7):3033-

26. Raboud JM, Major C, Sherlock C, O'Shaughnessy MV. The effects of pooling serum samples from seroconverting individuals or individuals with end stage disease for HIV antibody testing: a comparison of four screen tests and three pool sizes, Serodiagnosis and Immunotherapy in Infectious Disease. 1996;8(1),19- https://doi.org/10.1016/S0888-0786(96)80017-5

27. Salines M, Andraud M, Pellerin M, Bernard C, Grasland B, Pavio N, et al. Impact of porcine circovirus type 2 (PCV2) infection on hepatitis $E$ virus (HEV) infection and transmission under experimental conditions. Vet Microbiol. 2019;234:1-7 https://doi.org/10.1016/j.vetmic.2019.05.010.

28. Salines $M$, Dumarest $M$, Andraud M, Mahé $S$, Barnaud E, Cineux $M$, et al. Natural viral co-infections in pig herds affect hepatitis $E$ virus (HEV) infection dynamics and increase the risk of contaminated livers at slaughter. Transbound Emerg Dis. 2019;66:1930-45.

29. Yang Y, Shi R, She R, Mao J, Zhao Y, Du F, et al. Fatal disease associated with Swine Hepatitis E virus and Porcine circovirus 2 co-infection in four weaned pigs in China. BMC Veterinary Research (2015) 11:77. DOI 10.1186/s12917-015-0375-z.

30. Christianson WT, Choi CS, Collins JE, Molitor TW, Morrison RB, Joo HS. Pathogenesis of porcine reproductive and respiratory syndrome virus infection in mid-gestation sows and fetuses. Can $\mathrm{J}$ Vet Res. 1993;57(4):262-

31. Feng H, Segalés J, Fraile L, López-Soria S, Sibila M. Effect of high and low levels of maternally derived antibodies on porcine circovirus type 2 (PCV2) infection dynamics and production parameters in PCV2 vaccinated pigs under field conditions. Vaccine. 2016;34(27):3044-

32. Carasova P, Celer V, Takacova K, Trundova M, Molinkova D, Lobova D, et al. The levels of PCV2 specific antibodies and viremia in pigs. Res Vet Sci. 2007;83(2):274- DOI: 10.1016/j.rvsc.2006.11.13.

33. Grau-Roma L, Hjulsager CK, Sibila M, Kristensen CS, López-Soria S, Enøe C, et al. Infection, excretion and seroconversion dynamics of porcine circovirus type 2 (PCV2) in pigs from post-weaning multisystemic wasting syndrome (PMWS) affected farms in Spain and Denmark. Vet Microbiol. 2009;135(3-4):272- DOI: 10.1016/j.vetmic.2008.10.07. 
34. Meng XJ, Halbur PG, Shapiro MS, Govindarajan S, Bruna JD, Mushahwar IK, et al. Genetic and experimental evidence for cross-species infection by swine hepatitis $E$ virus. J Virol. 1998;72(12):9714-

35. Meng XJ, Purcell RH, Halbur PG, Lehman JR, Webb DM, Tsareva TS, et al. A novel virus in swine is closely related to the human hepatitis E virus. Proc Natl Acad Sci USA. 1997;94(18):9860-

36. Meng XJ, Halbur PG, Opriessnig T. Hepatitis E Virus. In: Zimmerman JJ, Karriker LA, Ramirez A, Schwartz KJ, Stevenson GW, editors. Diseases of Swine, 10th ed. Ames: lowa; 2012. p. 554-6.

37. Donadeu M, Arias M, Gomez-Tejedor C, Agüero M, Romero L, Christianson WT, Sánchez-Vizcaíno J. Using polymerase chain reaction to obtain PRRSV-free piglets from endemically infected herds. Swine Health Prod. 1999;7(6):255-61.

38. Grierson SS, King DP, Sandvik T, Hicks D, Spencer Y, Drew TW, et al. Detection and genetic typing of type 2 porcine circoviruses in archived pig tissues from the UK. Arch Virol. 2004;149(6):1171- DOI: 10.1007/s00705-003-0288-1.

39. Jothikumar N, Cromeans TL, Robertson BH, Meng XJ, Hill VR. A broadly reactive one-step real-time RT-PCR assay for rapid and sensitive detection of hepatitis E virus. J Virol Methods. 2006;131(1):65DOI: 10.1016/j.jviromet.2005.07.04. 